\title{
EVALUATION OF CERVICAL ALIGNMENT AND ITS RELATIONSHIP WITH THORACIC KYPHOSIS AND SPINOPELVIC PARAMETERS AFTER SCOLIOSIS CORRECTION SURGERY
}

\author{
AVALIAÇÃO DO ALINHAMENTO CERVICAL E SUA RELAÇÃO COM A CIFOSE TORÁCICA E \\ PARÂMETROS ESPINOPÉLVICOS APÓS CIRURGIA DE ÇORREÇÃO DE ESCOLIOSE
}

\author{
EVALUACIÓN DE LA ALINEACIÓN CERVICAL Y SU RELACIÓN CON LA CIFOSIS TORÁCICA Y \\ PARÁMETROS ESPINOPÉLVICOS DESPUÉS DE LA CIRUGÍA DE CORRECCIÓN DE ESCOLIOSIS
}

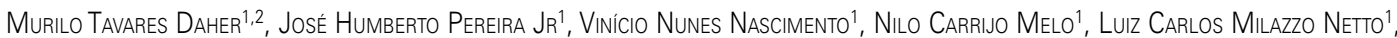 \\ Adriano Passágla Esperidião1, Pedro Felisbino Jri1, André luiz Passos Cardoso³, Brenda Cristina Ribeiro Araújo1, Sérgio Daher 1 \\ 1. Spine Group of the Centro de Reabilitação e Readaptação Dr. Henrique Santillo (CRER - Goiânia/GO), Goiânia, GO, Brazil. \\ 2. Department of Orthopedics and Traumatology of the Faculdade de Medicina da Universidade Federal de Goiás (DOT/FM/UFG), Goiânia, GO, Brazil. \\ 3. Hospital das Clínicas da Universidade Federal de Goiás (HC/UFG), Goiânia, GO, Brazil.
}

\begin{abstract}
Objectives: To evaluate the cervical alignment after the correction of idiopathic scoliosis using high screw density and direct vertebral derotation (DVD) and to correlate it with thoracic kyphosis, spinopelvic parameters, and quality of life. Methods: Retrospective cohort study. We assessed the medical records and radiographs of patients submitted to idiopathic scoliosis surgery using high density of pedicular screws (80\%) and DVD with at least 6 months of follow-up. All the radiographic parameters were evaluated in the preoperative period and in the last postoperative visit. Results: A total of 43 patients were evaluated, of which 35 (81\%) were female. The mean age was 15 years (11 to 30 years) with a mean follow-up of one year and four months. Regarding Lenke's classification, 14 were of group 1, five of group 2, 10 of group 3, eight of group 4, four of group 5 and two of group 6. Only four patients had sagittal modifier $(+)$ and two sagittal modifier (-). There was no significant difference between pre and postoperative thoracic kyphosis. When we evaluated the groups with,$+ \mathrm{N}$ and - thoracic modifiers, we observed hypokyphotic and normokyphotic patients (- and N) had an increase in kyphosis, whereas hyperkyphotic patients $(+)$ had a decrease. There was no statistical difference in relation to the radiographic parameters of the cervical spine in the pre and postoperative periods. There was a significant improvement in most of the parameters of the quality of life questionnaires, but no correlation with the cervical radiographic parameters. Conclusion: Correction of idiopathic scoliosis using a high density of pedicular screws and a direct vertebral derotation technique failed to improve thoracic kyphosis or change the cervical sagittal alignment, despite promoting a significant improvement in the parameters of quality of life questionnaires.
\end{abstract}

Keywords: Scoliosis; Treatment outcome; Quality of life; Orthopedic fixation devices.

\section{RESUMO}

Objetivos: Avaliar o alinhamento cenvical após a correção da escoliose idiopática utilizando alta densidade de parafusos e derrotação vertebral direta (DVD) e correlacionar com a cifose torácica, parâmetros espinopélvicos e qualidade de vida. Métodos: Estudo retrospectivo de coorte. Foram avaliados prontuários e radiografias de pacientes submetidos à cirurgia de escoliose idiopática utilizando alta densidade de parafusos pediculares (80\%) e DVD com pelo menos seis meses de seguimento. Todos os parâmetros radiográficos foram avaliados no pré-operatório e no último acompanhamento do pós-operatório. Resultados: Foram avaliados 43 pacientes, sendo 35 (81\%) do sexo feminino. A média de idade foi 15 anos (11 a 30 anos) com média de seguimento de um ano e quatro meses. Quanto à classificação de Lenke, 14 eram do grupo 1 , cinco do grupo 2, 10 do grupo 3, oito do grupo 4, quatro do grupo 5 e dois do grupo 6 . Apenas quatro pacientes apresentavam modificador sagital $(+)$ e dois, modificador sagital (-). Não houve diferença significativa entre a cifose torácica pré e pós-operatória. Quando avaliados os grupos com modificadores torácicos,$+ \mathrm{Ne}$-, constatamos que os pacientes hipocifóticos e normocifóticos (- e $\mathrm{N}$ ) tiveram aumento da cifose, enquanto os pacientes hipercifóticos (+) tiveram diminuição. Não houve diferença estatística em relação aos parâmetros radiográficos da coluna cenvical no pré e pós-operatório. Houve melhora significativa na maioria dos parâmetros dos questionários de qualidade de vida, mas sem nenhuma correlação com os parâmetros radiográficos cervicais. Conclusão: A correção da escoliose idiopática utilizando alta densidade de parafusos pediculares e técnica de derrotação vertebral direta não conseguiu melhorar a cifose torácica ou alterar o alinhamento sagital cervical, apesar de promover melhora significativa dos parâmetros dos questionários de qualidade de vida.

Descritores: Escoliose; Resultado do tratamento; Qualidade de vida; Dispositivos de fixação ortopédica.

\section{RESUMEN}

Objetivos: Evaluar la alineación cervical después de la corrección de la escoliosis idiopática utilizando alta densidad de tornillos y desrotación vertebral directa (DVD) y correlacionar con la cifosis torácica, parámetros espinopélvicos y calidad de vida. Métodos: Estudio retrospectivo de cohorte. Se evaluaron los historiales médicos y radiografías de pacientes sometidos a la cirugía de escoliosis idiopática utilizando alta densidad de tornillos pediculares (80\%) y DVD con al menos seis meses de seguimiento. Todos los parámetros radiográficos fueron evaluados en el preoperatorio y en el último seguimiento del postoperatorio. Resultados: Se evaluaron 43 pacientes, siendo 35 (81\%) 
del sexo femenino. El promedio de edad fue de 15 años (11 a 30 años) con una media de seguimiento de 1 año y cuatro meses. En cuanto a la clasificación de Lenke, 14 eran del grupo 1, cinco del grupo 2, 10 del grupo 3, ocho del grupo 4, cuatro del grupo 5 y dos del grupo 6. Sólo cuatro pacientes presentaban un modificador sagital (+) y dos, modificador sagital (-). No hubo diferencia significativa entre la cifosis torácica pre y postoperatoria. Cuando se evaluaron los grupos con modificadores torácicos,$+ N$ y -, constatamos que los pacientes hipocifóticos y normocifóticos (- y N) tuvieron aumento de la cifosis, mientras que los pacientes hipercifóticos (+) tuvieron disminución. No hubo diferencia estadística en relación a los parámetros radiográficos de la columna cervical en el pre y postoperatorio. Se observó una mejora significativa en la mayoría de los parámetros de cuestionarios de calidad de vida, pero sin ninguna correlación con los parámetros radiográficos cervicales. Conclusión: La corrección de la escoliosis idiopática utilizando alta densidad de tornillos pediculares y técnica de desrotación vertebral directa no logró mejorar la cifosis torácica o alterar la alineación sagital cervical, a pesar de promover una mejora significativa de los parámetros de los cuestionarios de calidad de vida.

Descriptores: Escoliosis; Resultado del tratamiento; Calidad de vida; Dispositivos de fijación ortopédica.

\section{INTRODUCTION}

Adolescent idiopathic scoliosis (AIS) is a three-dimensional deformity, usually associated with thoracic hypokyphosis. ${ }^{1-3}$ The hypokyphosis, according to Dickson, is a primordial factor in the development of the deformity. ${ }^{1-3}$

The surgical treatment of idiopathic scoliosis has undergone several advances in recent years. The advent of pedicle screws and direct vertebral derotation (DVD) techniques allowed better correction of deformity in the coronal and axial planes. ${ }^{4,5}$ Nevertheless, some authors have demonstrated that these techniques do not achieve the same success in correction of the sagittal plane, usually associated with worsening of thoracic kyphosis. ${ }^{6,7}$

The importance of the sagittal plane to the patient's quality of life and the complex mechanism of interaction between the curves of the different regions of the spine are increasingly recognized. This mechanism makes it possible for changes in thoracic kyphosis to have repercussions on cervical lordosis. ${ }^{8}$

The objective of this study was to evaluate the behavior of thoracic kyphosis following correction of deformity using high-density pedicle screws ${ }^{9}$ and DVD and to correlate changes in the cervical spine with spinopelvic parameters and quality of life questionnaires.

\section{METHODS}

\section{Patients}

This was a retrospective cohort study based on data collected prospectively. After the signing of the ICF and approval by the local IRB, we evaluated the medical records and imaging exams of patients submitted to surgical treatment for idiopathic scoliosis in a single center using high-density implants (more than $80 \%)^{9,10}$ and the direct vertebral derotation (DVD) technique ${ }^{4,5}$ with at least six months of follow-up.

All cases of non-idiopathic deformities (congenital, neurofibromatous, etc.) or where any other deformity correction technique (vertebral resection or three-column osteotomies) had been used were excluded. Cases lacking a complete set of examinations that would allow evaluation of the cervical spine and the spinopelvic parameters were also excluded.

\section{Surgical technique}

All patients were operated on by the same surgeon, always following the same technique. Intraoperative monitoring was used in all cases. After the usual subperiosteal exposure, bipedicular instrumentation of all levels in the area of arthrodesis was performed. Some pedicles were left without screws when they presented difficult cannulation or when electromyography showed some warning signal that the surgeon considered relevant. In the concavity of the curve, we used extended-head screws (listhesis reduction screws) to assist in the derotation of the axial plane and to improve the thoracic kyphosis. The correction always began in the concavity of the thoracic curves and in the convexity of the lumbar curves. The concavity rod was hypermolded and the convexity rod was hypomolded to assist the derotation of the curve and to try to improve correction of the thoracic kyphosis. After the derotation with the concavity rod, vertebra-by-vertebra derotation (DVD) was performed through screw extenders and distraction between the screws of the concavity. After this maneuver, the hypomolded convexity rod was put in place in order to further reduce the convexity. In more rigid curves, Ponte osteotomies ${ }^{11}$ were performed in order to give more flexibility to the deformity. (Figure 1)

\section{Clinical and radiographic analysis}

The clinical evaluation was conducted using the SF-36 (Short Form 36), Oswestry, and SRS-30 (Scoliosis Research Society) questionnaires, both preoperatively and at the last postoperative follow-up visit.

The radiographic evaluation was conducted using the following parameters: pelvic incidence (PI), pelvic tilt (PT), sacral inclination (SI), lumbar lordosis (LL), principal thoracic kyphosis T5-T12 (TK), thoraco-lumbar transition kyphosis T10-L2 (TLK), sagittal vertical axis (SVA), and the Cobb angles of the proximal thoracic curve, the principal thoracic curve, and the thoraco-lumbar/ lumbar curve. ${ }^{12,13}$

The parameters related to the cervical spine were: ${ }^{14}$ (Figure 2) Cervical lordosis $(\mathrm{CL})$ : the angle measured between the lower plateau of $\mathrm{C} 2$ and the upper plateau of $\mathrm{C} 7$ using the Cobb method.

C1-C2 angulation (C1-C2): the angle formed by the line that connects the anterior and posterior arches of $\mathrm{C} 1$ and the line that passes through the lower plateau of C2.

T1 Slope (T1S): the angle formed by the line that passes through the upper plateau of $\mathrm{T} 1$ and the horizontal.

Proximal thoracic kyphosis T1-T5 (PTK T1-T5): the angle between the upper plateau of $\mathrm{T} 1$ and the lower plateau of $\mathrm{T} 5$ using the Cobb method. Cervical sagittal vertical axis (CSVA): the horizontal distance between the center of $\mathrm{C} 2$ and the posterior portion of the upper plateau of $\mathrm{C} 7$.

All the radiographic examinations were conducted following a well-established protocol. ${ }^{15}$ The measurements of the preoperative radiographs and those from the final follow-up visit were taken by the same examiner using Surgimap Spine ${ }^{16}$ software (Nemaris Inc., New York, NY).

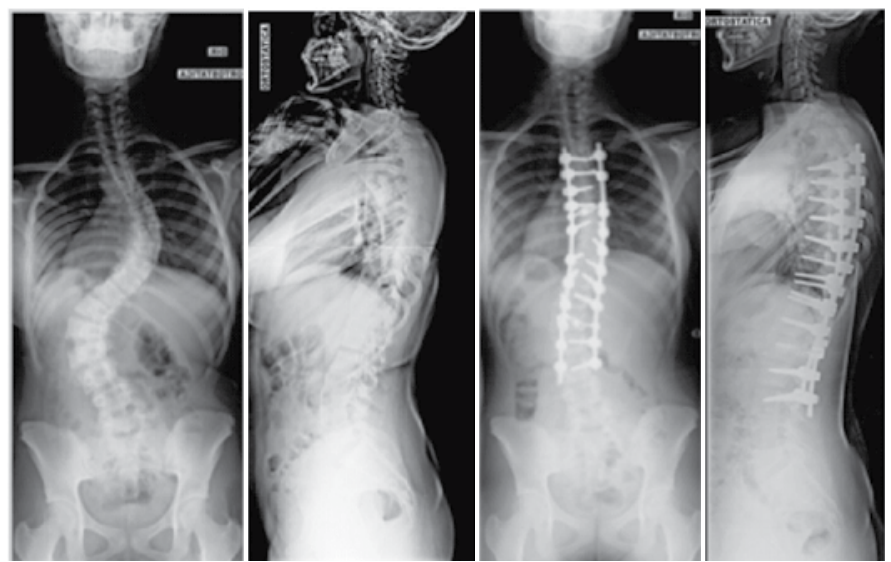

Figure 1. Example of a patient operated using the direct vertebral derotation (DVD) technique and high-density screws. 


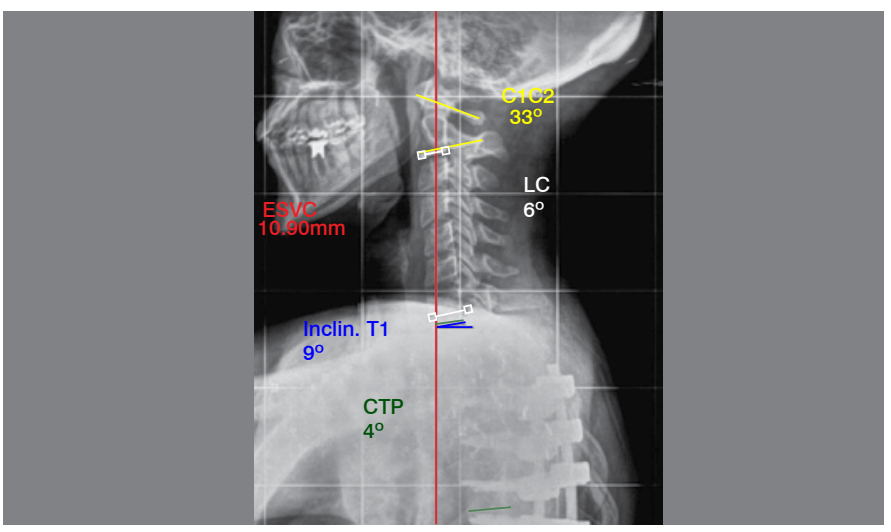

Figure 2. Radiographic cervical parameters.

\section{Statistical analysis}

All the statistical analyses were conducted using SPSS (version 23.0, IBM SPSS, Inc.). All data were presented as averages with standard deviation. The paired Wilcoxon test was used to compare the changes in radiographic parameters in the pre- and postoperative periods. The Spearman test was used to assess the correlation between the radiographic changes and the quality of life scales. All the tests were applied accepting a probability of error of $5 \%$ and considering a confidence interval of $95 \%$.

\section{RESULTS}

We evaluated 43 patients, 8 (19\%) male and 35 (81\%) female. The average age was 15 years (11 to 30 years of age) with an average follow-up of one year and four months (minimum six months and maximum of three years and four months).

In terms of the Lenke classification, 14 were type 1 (8 1AN, 2 $1 \mathrm{BN}, 1 \mathrm{CN}, 21 \mathrm{~A}+, 11 \mathrm{~A}-)$, five were type 2 (1 2AN, $22 \mathrm{BN}, 12 \mathrm{CN}$, $12 \mathrm{~A}+$ ), 10 were type 3 (13AN, $13 \mathrm{BN}, 73 \mathrm{CN}, 13 \mathrm{C}+$ ), eight were type 4 (4 4AN, $14 \mathrm{BN}, 24 \mathrm{CN}, 14 \mathrm{C}$-), four were type 5 (4 5CN), and two were type $6(26 \mathrm{CN})$. Only four patients had thoracic kyphosis (TK) greater than $40^{\circ}$ and two patients less than $10^{\circ}$. Most patients (37) fell into group $\mathrm{N}$ (TK between 10 and $40^{\circ}$ ).

The proximal level of the arthrodesis was T3 in six patients, T4 in 24 patients, $\mathrm{T} 5$ in five patients, $\mathrm{T} 7$ and $\mathrm{T} 8$ in one patient, and T9 and T10 in three patients. The distal level of the arthrodesis was T12 in four patients, L1 in nine, L2 in 6, L3 in 18, and L4 in six patients. Six patients were submitted to selective lumbar arthrodesis.

In the coronal plane we had a correction of proximal thoracic curve of $44 \%$, of the principal thoracic curve of $60.7 \%$, and of the thoraco-lumbar/lumbar curve of $62.3 \%$. When the six cases of selective lumbar arthrodesis were excluded, the correction of the proximal thoracic curve was $64 \%$.

The average thoracic kyphosis (TK) was $26.4^{\circ}( \pm 6.5)$ in the preoperative period and $29^{\circ}( \pm 6.3)$ in the postoperative period ( $p$ 0.461). When we compared the behavior of TK in relation to the preoperative value (TK $<10^{\circ}, 10^{\circ}<\mathrm{TK}<40^{\circ}$ and $\mathrm{TK}>40^{\circ}$ ), we had an increase in kyphosis in hypokyphotic and normokyphotic cases and a reduction in the hyperkyphotic cases (p 0.003). (Table 1)

Table 2 shows the behavior of the radiographic parameters related to the cervical spine. There was no statistically significant change in relation to the pre- and postoperative periods except in relation to the cervical sagittal vertical axis (CSVA). Nor was there any statistical difference when the patients were separated by the degree of thoracic kyphosis $\left(\mathrm{TK}<10^{\circ}, 10^{\circ}<\mathrm{TK}<40^{\circ}\right.$ and $\left.\mathrm{TK}>40^{\circ}\right)$ (Table 3) and the degree of pelvic incidence $\left(\mathrm{PI}<40^{\circ}, 40^{\circ}<\mathrm{PI}<\right.$ 60 , and $\mathrm{PI}>60^{\circ}$ ). (Table 4).

Regarding the data from the quality of life questionnaires, almost all of the parameters improved in the postoperative period in relation to the preoperative values. (Table 5) However, there was no correlation between this improvement and any change in the cervical radiographic parameters.
Table 1. Behavior of thoracic kyphosis in the pre- and postoperative periods in relation to initial thoracic kyphosis.

\begin{tabular}{c|c|c|c|c}
\hline & \multicolumn{3}{|c|}{ Thoracic Kyphosis } & \\
\hline Variable & $\begin{array}{c}\text { Hypokyphosis } \\
(<10)\end{array}$ & $\begin{array}{c}\text { Normokyphosis } \\
(10 \mathrm{a} 40)\end{array}$ & $\begin{array}{c}\text { Hyperkyphosis } \\
(>40)\end{array}$ & $\mathrm{p}$ \\
\hline & $(\mathrm{N}=2)$ & $(\mathrm{N}=35)$ & $(\mathrm{N}=6)$ & \\
\hline TK & & & & 0.003 \\
\hline Average $\pm \mathrm{SD}$ & $16.5 \pm 7.78$ & $2.63 \pm 9.65$ & $-10.33 \pm 5.89$ & \\
\hline
\end{tabular}

Table 2. Changes of the cervical radiographic parameters in the pre- and postoperative periods. CSVA - cervical sagittal vertical axis - measured in $\mathrm{mm}$.

\begin{tabular}{c|c|c|c|c}
\hline Variable & Pre & Post & Change & p \\
\hline C1-C2 Angle & & & & 0.461 \\
\hline Average \pm SD & $-27.6 \pm 6.5$ & $-29 \pm 6.3$ & $1.19 \pm 8.25$ & \\
\hline Cervical Lordosis & & & & 0.552 \\
\hline Average \pm SD & $11.4 \pm 8.3$ & $10.2 \pm 5.7$ & $-1.19 \pm 9.12$ & \\
\hline T1 SLOPE & & & & 0.911 \\
\hline Average \pm SD & $16.3 \pm 7.5$ & $16.2 \pm 6.2$ & $-0.14 \pm 8.34$ & \\
\hline $\begin{array}{c}\text { T1-T5 Proximal } \\
\text { thoracic kyphosis }\end{array}$ & & & & 0.067 \\
\hline Average \pm SD & $8.4 \pm 7.5$ & $11.3 \pm 7.2$ & $2.95 \pm 10.01$ & \\
\hline CSVA & & & & 0.028 \\
\hline Average \pm SD & $16.9 \pm 7$ & $20.5 \pm 7.2$ & $3.52 \pm 8.33$ &
\end{tabular}

Table 3. Behavior of the cervical radiographic parameters in relation to preoperative kyphosis. CSVA - cervical sagittal vertical axis - measured in $\mathrm{mm}$.

\begin{tabular}{c|c|c|c|c}
\hline \multicolumn{5}{c}{ Cifose Torácica } \\
\hline Variable & $\begin{array}{c}\text { Hypokyphosis } \\
(<\mathbf{1 0})\end{array}$ & $\begin{array}{c}\text { Normokyphosis } \\
(\mathbf{1 0} \mathbf{a} \mathbf{4 0})\end{array}$ & $\begin{array}{c}\text { Hyperkyphosis } \\
(\mathbf{>} \mathbf{4 0})\end{array}$ & $\mathbf{p}$ \\
\hline & $(\mathrm{N}=2)$ & $(\mathrm{N}=35)$ & $(\mathrm{N}=6)$ & \\
\hline C1-C2 Angle & & & & 0.755 \\
\hline Average \pm SD & & $1.41 \pm 8.96$ & $0.2 \pm 4.44$ & \\
\hline Cervical Lordosis & & & & 0.276 \\
\hline Average \pm SD & $5 \pm 1.41$ & $-1.29 \pm 9.94$ & $-2.67 \pm 2.88$ & \\
\hline T1 SLOPE & & & & 0.163 \\
\hline Average \pm SD & $9.5 \pm 3.54$ & $-0.97 \pm 8.64$ & $1.5 \pm 5.36$ & \\
\hline $\begin{array}{c}\text { T1-T5 Proximal } \\
\text { thoracic kyphosis }\end{array}$ & & & & 0.910 \\
\hline Average \pm SD & $4.5 \pm 13.44$ & $2.94 \pm 9.97$ & $2.5 \pm 11.31$ & \\
\hline CSVA & & & & 0.928 \\
\hline Average $\pm S D$ & $6.79 \pm 14.81$ & $3.48 \pm 8.07$ & $2.65 \pm 9.6$ & \\
\hline
\end{tabular}

Table 4. Behavior of the cervical radiographic parameters in relation to preoperative pelvic incidence (PI). CSVA - cervical sagittal vertical axis measured in $\mathrm{mm}$.

\begin{tabular}{|c|c|c|c|c|}
\hline \multirow[b]{2}{*}{ Variable } & \multicolumn{3}{|c|}{ PI } & \multirow[b]{2}{*}{ p } \\
\hline & $\begin{array}{l}\text { Small } \\
(<40)\end{array}$ & $\begin{array}{l}\text { Medium } \\
\text { (40 to } 60)\end{array}$ & $\begin{array}{l}\text { Large } \\
(>60)\end{array}$ & \\
\hline & $(\mathrm{N}=12)$ & $(\mathrm{N}=22)$ & $(\mathrm{N}=9)$ & \\
\hline C1-C2 Angle & & & & 0.586 \\
\hline Average $\pm S D$ & $1.14 \pm 9.48$ & $0.6 \pm 8.97$ & $3 \pm 4.58$ & \\
\hline Cervical Lordosis & & & & 0.348 \\
\hline Average $\pm \mathrm{SD}$ & $-3 \pm 8.87$ & $1.23 \pm 8.62$ & $-4.67 \pm 9.92$ & \\
\hline T1 SLOPE & & & & 0.850 \\
\hline Average \pm SD & $0.92 \pm 8.58$ & $-0.32 \pm 8.16$ & $-1.11 \pm 9.31$ & \\
\hline $\begin{array}{l}\text { T1-T5 Proximal } \\
\text { thoracic kyphosis }\end{array}$ & & & & 0.740 \\
\hline Average $\pm S D$ & $4.92 \pm 6.16$ & $2.09 \pm 10.74$ & $2.44 \pm 12.76$ & \\
\hline CSVA & & & & 0.905 \\
\hline Average \pm SD & $3.91 \pm 9.05$ & $2.95 \pm 7.4$ & $4.38 \pm 10.3$ & \\
\hline
\end{tabular}


Table 5. Pre- and postoperative evaluation of quality of life questionnaires.

\begin{tabular}{|c|c|c|c|c|}
\hline Variable & Pre & Post & Change & $\mathbf{p}$ \\
\hline SRS-30 & & & & 0.002 \\
\hline Average \pm SD & $3.8 \pm 0.59$ & $4.2 \pm 0.4$ & $-0.46 \pm 0.68$ & \\
\hline OSWESTRY & & & & 0.001 \\
\hline Average \pm SD & $15.1 \pm 14$ & $6.8 \pm 7.7$ & $9.2 \pm 14.1$ & \\
\hline $\begin{array}{l}\text { SF-36 Limitation by } \\
\text { physical aspect }\end{array}$ & & & & 0.022 \\
\hline Average \pm SD & $71.7 \pm 23.6$ & $77.8 \pm 23.6$ & $11.9 \pm 24.5$ & \\
\hline Median (min.; max.) & $75(25 ; 100)$ & $85(5 ; 100)$ & $10(-40 ; 75)$ & \\
\hline SF-36 Functional capacity & & & & 0.003 \\
\hline Average \pm SD & $60.1 \pm 22.4$ & $75 \pm 22.9$ & $21.5 \pm 28.4$ & \\
\hline Median (min.; max.) & $63(25 ; 100)$ & $75(25 ; 100)$ & $25(-37 ; 75)$ & \\
\hline SF-36 Pain & & & & 0.016 \\
\hline Average $\pm \mathrm{SD}$ & $62.5 \pm 24.7$ & $72.4 \pm 22.6$ & $15.7 \pm 27$ & \\
\hline Median (min.; max.) & $62(22 ; 100)$ & $72(31 ; 100)$ & $4.5(-22 ; 69)$ & \\
\hline SF-36 Vitality & & & & 0.032 \\
\hline Average \pm SD & $60.9 \pm 21.2$ & $66.6 \pm 18.2$ & $9.1 \pm 20.4$ & \\
\hline Median (min.; max.) & $59.5(13 ; 94)$ & $69(19 ; 100)$ & $12(-37 ; 50)$ & \\
\hline SF3-6 Social aspect & & & & 0.048 \\
\hline Average \pm SD & $78.3 \pm 23$ & $85.9 \pm 18$ & $9.3 \pm 22.7$ & \\
\hline Median (min.; max.) & $81.5(25 ; 100)$ & $88(25 ; 100)$ & $6(-50 ; 50)$ & \\
\hline $\begin{array}{l}\text { SF-36 Limitation by } \\
\text { emotional aspect }\end{array}$ & & & & 0.002 \\
\hline Average \pm SD & $63.8 \pm 19.9$ & $82.5 \pm 21.3$ & $19.5 \pm 24.7$ & \\
\hline Median (min.; max.) & $66.5(25 ; 100)$ & $92(25 ; 100)$ & $21(-25 ; 75)$ & \\
\hline SF-36 Mental health & & & & 0.606 \\
\hline Average \pm SD & $65.83 \pm 22.54$ & $66.8 \pm 24.5$ & $2.3 \pm 33$ & \\
\hline Median (min.; max.) & $75(10 ; 95)$ & $70(5 ; 100)$ & $5(-80 ; 90)$ & \\
\hline $\begin{array}{l}\text { SF-36 General } \\
\text { state of health }\end{array}$ & & & & 0.057 \\
\hline Average $\pm S D$ & $70.8 \pm 24.7$ & $74 \pm 19.4$ & $8 \pm 21.4$ & \\
\hline Median (min.; max.) & $73.5(15 ; 100)$ & $77(32 ; 100)$ & $9(-50 ; 55)$ & \\
\hline
\end{tabular}

\section{DISCUSSION}

Idiopathic scoliosis is a three-dimensional deformity characterized by thoracic kyphosis ${ }^{1-3}$ and reestablishing the sagittal plane is a big challenge in the treatment of this deformity.

Pedicle screws, although widely used, seem to worsen the hypokyphosis. ${ }^{17,18}$ There are reports of reduction of kyphosis ranging from 3 to $14^{\circ} .{ }^{19}$ The same has been described in relation to the DVD technique - that despite an improvement in axial correction, seems to reduce thoracic kyphosis. ${ }^{19}$ In our case series, although we achieved an increase in thoracic kyphosis $\left(2.6^{\circ}\right)$, it was not statistically significant. Nevertheless, we observed different behavior in the curves according to the initial TK. The cases with $>40^{\circ}$ had an average postoperative reduction of $10^{\circ}$, while the cases with $\mathrm{TK}$ $<10^{\circ}$ and those with TK between 10 e $40^{\circ}$ had increases of $16.5^{\circ}$ and $2.6^{\circ}$, respectively.

We believe that the reduction in thoracic kyphosis is a consequence of the greater derotation of these techniques, allowing the real profile of the deformity to be better evaluated in the lateral radiograph. ${ }^{19}$ This was partially demonstrated by Newton et al., ${ }^{20}$ who evaluated the angulation between each segment using EOS and observed segmental kyphosis in the curve that is underestimated by the standard radiographic technique. This shows that we have little capacity to produce kyphosis using current posterior techniques, probably because of the conformation of the vertebrae in the structured curves (greater height of the vertebral body in the anterior region and in the convexity in relation to the posterior region and the concavity). ${ }^{19}$

This inability to reestablish the sagittal plane appears to be the cause of the radiographic changes found in the cervical spine. Hwang et al. ${ }^{21}$ studied 22 patients with Lenke 1 and 2 idiopathic scoliosis treated with posterior fixation with pedicle screws and showed that the six patients with preoperative frank cervical kyphosis $\left(\mathrm{CL}>0^{\circ}\right)$ remained so following surgical treatment. Of the other 16 patients with good preoperative alignment, eight evolved with frank cervical kyphosis and eight remained with lordosis or neutral. When they compared the patients whose cervical alignment had worsened in relation to those who had maintained cervical alignment, they observed that those with worsened cervical alignment had a greater reduction in thoracic kyphosis (TK from 46 to $25^{\circ}$ compared to 44 to $44^{\circ}$ ). They concluded that a reduction of thoracic kyphosis may predispose the cervical spine to decompensation. ${ }^{21}$

Canavese et al. ${ }^{22}$ also evaluated the behavior of cervical alignment following scoliosis correction surgery using a hybrid system (hooks and screws) in 32 patients. In their study, thoracic kyphosis remained practically constant (from $32.3^{\circ}$ to $30.4^{\circ}$ ). As in our case series, there was no change in the postoperative cervical parameters as compared to the postoperative values.

Ilharreborde et al. ${ }^{23}$ also evaluated the behavior of cervical alignment, but using a sublaminar band fixation system. In their study, they observed an average increase in thoracic kyphosis of $14.5^{\circ}$ and an average increase in cervical lordosis of $18.8^{\circ}$. The sublaminar band system is a fixation method that seems to preserve or increase thoracic kyphosis and this may explain the improved cervical lordosis. ${ }^{23}$ However, we question whether this increase in thoracic kyphosis is real or just the small rotation correction that this system causes. Our study is the only one in the literature that assesses the behavior of the cervical spine using more modern deformity correction techniques like pedicle screws with high implant density and DVD

Although there was no improvement in either thoracic kyphosis or cervical alignment, there was a significant improvement in the quality of life parameters between the pre- and postoperative assessments, without any correlation between these parameters and the cervical parameters.

\section{CONCLUSIONS}

The correction of idiopathic scoliosis using high-density pedicle screws and the direct vertebral rotation technique did not improve cervical kyphosis or change sagittal vertebral alignment, despite promoting a significant improvement in the parameters of the quality of life questionnaires.

All authors declare no potential conflict of interest related to this article. 


\section{REFERÊNCIAS}

1. Kojima T, Kurokawa T. Quantitation of three-dimensional deformity of idiopathic scoliosis. Spine (Phila Pa 1976). 1992:17(3 Suppl):S22-9.

2. Dickson RA, Lawton JO, Archer IA, Butt WP. The pathogenesis of idiopathic scoliosis. Biplanar spinal asymmetry. J Bone Joint Surg Br. 1984;66(1):8-15.

3. Dickson RA. Pathogenesis of idiophatic scoliosis. In: Newton PO, O'Brien MF Shufflebarger HL, Betz RR, Dickson RA, Harms J, editors. Idiophatic scoliosis: The Harms study group treatment guide. New York: Thieme; 2010. p. 28-50.

4. Suk SI. Pedicle screw instrumentation for adolescent idiopathic scoliosis: the in sertion technique, the fusion levels and direct vertebral rotation. Clin Orthop Surg. $2011 ; 3(2): 89-100$.

5. Lee SM, Suk SI, Chung ER. Direct vertebral rotation: a new technique of three-dimensional deformity correction with segmental pedicle screw fixation in adolescent idiopathic scoliosis. Spine (Phila Pa 1976). 2004;29(3):343-9.

6. Imrie M, Yaszay B, Bastrom TP, Wenger DR, Newton PO. Adolescent idiopathic scoliosis: should 100\% correction be the goal? J Pediatr Orthop. 2011:31(1 Suppl):S9-13.

7. Mladenov KV, Vaeterlein C, Stuecker R. Selective posterior thoracic fusion by means of direct vertebral derotation in adolescent idiopathic scoliosis: effects on the sagittal alignment. Eur Spine J. 2011;20(7):1114-7.

8. Ha Y, Schwab F, Lafage V, Mundis G, Shaffrey C, Smith J, et al. Reciprocal changes in cervical spine alignment after corrective thoracolumbar deformity surgery. Eur Spine J. 2014;23(3):552-9.

9. Daher MT, Cavali PTM, Santo MAM, Rossato AJ, Lehoczki MA, Landim E. Correlação entre o número de parafusos e o percentual de correção no tratamento cirúrgico da escoliose neuromuscular. Coluna/Columna. 2009;8(2):105-9.

10. Gotfryd AO, Avanzi O. Randomized Clinical Study on Surgical Techniques With Different Pedicle Screw Densities in the Treatment of Adolescent Idiopathic Scoliosis Types Lenke $1 \mathrm{~A}$ and 1B. Spine Deform. 2013;1(4):272-9.

11. Geck MJ, Macagno A, Ponte A, Shufflebarger HL. The Ponte procedure: posterior only treatment of Scheuermann's kyphosis using segmental posterior shortening and pedicle screw instrumentation. J Spinal Disord Tech. 2007;20(8):586-93.

12. Pratali RR, Hennemann SA, Amaral R, Silva LEC, Carvalho MOP, Daher MT, et al. Standardized terminology of adult spine deformity for Brazilian Portuguese. Coluna/Columna. 2015;14(4):281-5
13. O'Brien MF, KukloTR, Blanke KM, Lenke LG. Radiographic Measurements Manual: Spinal Deformity Study Group. Memphis, TN: Medtronic Sofamor Danek, USA; 2004

14. Scheer JK, Tang JA, Smith JS, Acosta FL Jr, Protopsaltis TS, Blondel B, et al. Cervica spine alignment, sagittal deformity, and clinical implications: a review. J Neurosurg Spine. 2013:19(2):141-59.

15. Schwab F, Lafage V, Patel A, Farcy JP. Sagittal plane considerations and the pelvis in the adult patient. Spine (Phila Pa 1976). 2009;34(17):1828-33.

16. Vila-Casademunt A, Pellisé F, Acaroglu E, Pérez-Grueso FJ, Martín-Buitrago MP, Sanli T, et al. The reliability of sagittal pelvic parameters: the effect of lumbosacral instrumentation and measurement experience. Spine (Phila Pa 1976). 2015:40(4):E253-8.

17. Vora V, Crawford A, Babekhir N, Boachie-Adjei O, Lenke L, Peskin M, et al. A pedicle screw construct gives an enhanced posterior correction of adolescent idiopathic scoliosis when compared with other constructs: myth or reality. Spine (Phila Pa 1976). 2007;32(17):1869-74

18. Potter BK, Kuklo TR, Lenke LG. Radiographic outcomes of anterior spinal fusion versus posterior spinal fusion with thoracic pedicle screws for treatment of Lenke Type I adolescent idiopathic scoliosis curves. Spine (Phila Pa 1976). 2005;30(16):1859-66.

19. Watanabe K, Nakamura T, Iwanami A, Hosogane N, Tsuji T, Ishii K, et al. Vertebral derotation in adolescent idiopathic scoliosis causes hypokyphosis of the thoracic spine. BMC Musculoskelet Disord. 2012;13:99

20. Newton PO, Fujimori T, Doan J, Reighard FG, Bastrom TP, Misaghi A. Defining the "Three-Dimensional Sagittal Plane" in Thoracic Adolescent Idiopathic Scoliosis. J Bone Joint Surg Am. 2015;97(20):1694-701.

21. Hwang SW, Samdani AF, Tantorski M, Cahill P, Nydick J, Fine A, et al. Cervical sagittal plane decompensation after surgery for adolescent idiopathic scoliosis: an effect imparted by postoperative thoracic hypokyphosis. J Neurosurg Spine. 2011;15(5):491-6.

22. Canavese F, Turcot K, De Rosa V, de Coulon G, Kaelin A. Cervical spine sagittal alignment variations following posterior spinal fusion and instrumentation for adolescent idiopathic scoliosis. Eur Spine J. 2011;20(7):1141-8.

23. Itharreborde B, Vidal C, Skalli W, Mazda K. Sagittal alignment of the cervical spine in adolescent idiopathic scoliosis treated by posteromedial translation. Eur Spine J. 2013;22(2):330-7. 